\title{
Balkanologie
}

Balkanologie Revue d'études pluridisciplinaires

Vol. $15 n^{\circ} 1 \mid 2020$

Mémoires performatives : faire des passés et des présents

\section{Questioning Western Approaches to Religion in the Former Yugoslavia}

Remise en question de l'opérationnalisation occidentale de la religion en exYougoslavie

Bojan Aleksov

OpenEdition

Journals

Electronic version

URL: https://journals.openedition.org/balkanologie/2526

DOI: 10.4000/balkanologie.2526

ISSN: 1965-0582

\section{Publisher}

Association française d'études sur les Balkans (Afebalk)

\section{Electronic reference}

Bojan Aleksov, "Questioning Western Approaches to Religion in the Former Yugoslavia", Balkanologie [Online], Vol. 15 n $^{\circ}$ | 2020, Online since 01 June 2020, connection on 05 August 2021. URL: http:// journals.openedition.org/balkanologie/2526 ; DOI: https://doi.org/10.4000/balkanologie.2526

This text was automatically generated on 5 August 2021 .

(C) Tous droits réservés 


\title{
Questioning Western Approaches to Religion in the Former Yugoslavia
}

\author{
Remise en question de l'opérationnalisation occidentale de la religion en ex- \\ Yougoslavie
}

Bojan Aleksov

1 The role of religion in the Yugoslav crisis, as well as in the lengthy and still ongoing tensions following its dissolution, has been the matter of continuous and at times hefty debate. More specifically, a number of studies have clearly demonstrated not only the manipulation of religion in the hands of nationalists but also the tacit support that churches and religious communities lent to warring factions in the former Yugoslavia. ${ }^{1}$ Others characterised the involvement of organised religion in the former Yugoslavia as a challenge to democratic pluralism and a serious threat to interethnic peace and coexistence. Looking closer at most of these accounts, no author singled out the essential features of religion, such as claims of truth or righteousness from God, but rather the specific political uses that religious, and often nonreligious, actors made of these claims. In the context of the overlap of ethnic and confessional boundaries among South Slavs, these claims emphasised the differences and fostered ethno-confessional homogenisation that underlied the rise of animosity, thus contributing to, rather than causing, the escalation of conflict and protracted tensions thereafter. Initially, the preponderant role of religion in Yugoslav conflict was attributed by foreign observers to the country's Orthodox-Byzantine and Islamic-Ottoman legacy, considered one of the chief markers that distinguished it from Western Europe. In the meantime, historical research has delegitimised this view, offering a more differentiated approach, especially illuminating the contribution of nationalism as a "Western" import, which spurred the notorious identification of religion and nation among Serbs, Croats and, more recently, Bosnyak Muslims, and enthused much of modern-day conflicts among ex-Yugoslavia's confessionally mixed populations. ${ }^{2}$

2 The last few decades have also witnessed the resurgence of strength of organised religion globally, which has been widely associated with the renewed visibility of the concept of civilisation, whereby Islam, Christianity and so on are becoming central 
political categories, the so-called "frames of reference", increasingly embedded in the discourses and shaping the practices of both religious and non-religious actors in international politics. ${ }^{3}$ While this trend is the focus of much of the burgeoning scholarship, there has been little empirical analysis of the particular context of Yugoslav successor states, where the defeat or high cost of the nationalist projects of the 1990s also saw the rise of political uses of religion in their aftermath as their continuations or substitutes. Instead, the copious body of literature on the role of religion in the wars in former Yugoslavia in the 1990s was significantly deepened only with attempts to trace the relations between local Muslims and Islamic faith-based organisations with their partners abroad, especially in the case of the so-called Islamic connections. ${ }^{4}$ At the same time, the interaction between religious leaders and organisations in former Yugoslavia and the West, and the approaches to organised religion by the West, have so far almost completely avoided scholarly examination. By "West", this article implies concrete actions and policies of major representatives or organisations of a few West European countries and the USA, which were most heavily involved in the Yugoslav conflict and its reconciliation. Given the fact that all of the successor states of Yugoslavia have striven towards associating with Western military, political and economic structures, be it by membership of NATO or the EU, "Western" involvement, as defined above, requires the most scrutiny without denying the need to explore "Islamic" or "Russian" connections. In order to address a number of ways in which the Western connections with local religious organisations took shape, this article will use a wide-ranging notion of approaches to religion. This term clearly excludes spiritual, theological, ecclesiastical or pastoral links. In addition, it will address the activities aimed at "inter-religious dialogue", which until recently also escaped the serious scrutiny and review processes that most other charitable and nongovernmental associations have undergone. ${ }^{5}$ The results of empirical research on the political and social presence of religious organisations and interreligious activities by scholars from the region will be combined with long-term observation of policies of Western state and non-state actors in order to deduce causal or simply cumulative effects.

3 The following undertaking can have implications for other conflict-ridden regions where Western involvement has experienced a similar shift towards engaging, reaching out and connecting with religious groups and leaders. This noticeable shift, especially in American foreign policy in recent decades, has followed the global resurgence of religion, whose growing political salience in public life and international politics was variably deemed to have started in the 1960s, 1979, at the end of Cold War or especially after September 11, 2001. ${ }^{6}$ After sociologists and political scientists clearly established that the public significance of religion, both in terms of practice and identity boundary, was on the rise, rejecting previous secularisation theories, ${ }^{7}$ a decade later many studies looked at its causes, manifestations and effects on international relations practices and theory. ${ }^{8}$ In their recent book, Philpott, Shah and Toft emphasised that never before in modern history did major religious actors enjoy greater capacity for political influence. What is even more significant is that the resurgence of religion does not imply solely a sociopolitical process, commonly known as politicization of religion, whereby religious actors develop activist political theologies and become more engaged in public debates and political practices. As Bettiza demonstrated, it appears also as a religionization of politics, whereby religious discourses and identities, and the practices and and symbols associated with them, are becoming more and more politically salient and publicly 
pervasive. ${ }^{9}$ Most successor states of Yugoslavia provide ample evidence of both sociopolitical processes. At the same time, the whole region was profoundly affected by policies and interventions of the Western political, educational, humanitarian and media agents and agencies, heavily engaging with local religious organisations and actors as well.

4 For practical purposes, the Western approaches to organised religion in former Yugoslavia in this article will be divided into three mutually related and overlapping areas:

1. Symbolic promotion of religious leadership;

2. Political, legal and financial involvement and policies;

3. Fostering interfaith dialogue and reconciliation.

5 The ensuing analysis will examine to what extent policies and international involvement affect ethno-confessional segmentation, political attitudes of religious leaders and institutions and contribute to the goal of stabilisation and peaceful reintegration of the region to Europe and the wider world, which most of them purport to achieve. It will remain at macro-level, thus not accounting for eventual dissenting individual actions or initiatives.

\section{Symbolic promotion of religious leadership}

6 Ever since conflicts erupted in what was still Yugoslavia in 1991, international - in most cases Western - political actors introduced a completely novel practice of meeting local religious leaders, which by now has become a ubiquitious part of every visit from power holders from the European Union and US, as well as part of the portfolio of their permanent diplomatic representatives on the ground. Initially it was believed that the religious leaders could act as mediators and call for peaceful solution, yet this hope never materialised..$^{10}$ The premise to consult or try to influence all stakeholders, including confessional leaders, might have been justified given the authoritarian tendencies of the rule of both Slobodan Milošević and Franjo Tuđman, and the war circumstances in Bosnia and Herzegovina. Yet after the end of fighting, Serbia and Croatia (and eventually Bosnia too) saw an internationally approved democratic transition. Their new authorities have been legitimate and cooperative, but the contacts with religious leaders continued.

7 This novel practice of engagement with religious leaders is reminiscent of Ottoman times and the so-called millet system, in which confessional leaders indeed carried secular powers. ${ }^{11}$ However, this task of the religious hierarchies, extinct for two centuries, did not envisage national representation, as it predated the nation-building epoch. In fact, the importance of religious leadership withered away once national secular leaders emerged in the 19th century, while traditional millet segregation and representation only contributed to the blurring of religious and national identities in the region that is now again intensified. Therefore, its reasoning needs to be located elsewhere. While a direct link could not be established, the Western representatives' engagement with Serbian/Croatian/Bosnian religious leaders coincided with the major shift in American foreign policy with the passing of laws and creation of fora advocating religious liberties and incorporating religion as a means to prevent or resolve identity-based conflicts. ${ }^{12}$ The new foreign policy approach or regimes, as 
Bettiza termed them, are influencing and transforming religious and secular landscapes worldwide. ${ }^{13}$ As Sam Brownback, Trump administration Ambassador-atLarge for International Religious Freedom, explained after his recent 10-day tour of the region, while much of the nature of the centuries-long Balkans conflict (sic) centred around a division based upon different faiths, the moment has now come as there is the right religious and political leadership "to build that long-term, durable foundation for peace." 14 Thus, we note that after half a century of forced and prolonged exclusion of religious leaders from political decision-making during Communist rule in Yugoslavia, the Western contacts have added symbolic weight to their ever-growing prominence in post-Yugoslav states. Thanks to ample media coverage, consciously or inadvertently this practice contributes to promoting local religious hierarchs into national leaders although they officially wield no political power in secular and democratic states created after the breakup of Yugoslavia. Moreover, both symbolically and literally, as in the statement above, Western contacts distort the causes of conflicts and influence the reconciliation by preselection of partners.

One explanation for the, by now ubiquitous, visits to bishops and muftis is that they represent a sort of new secret diplomacy. Clearly, this constitutes more than a matter of protocol or exercise in good manners and respect, as is evident from the frequent preselection of religious leaders as partners, disregarding strict hierarchical and canonical regulations. In the case of Kosovo, whose status and position of its ethnic groups is still unresolved, international mediators in the past decades switched partners in the Serbian Orthodox Church from Patriarch(ate) to local bishop (Artemije) to the heads of the biggest monastery, Dečani (abbots Sava and Teodosije, who replaced the uncooperative Artemije as bishop), depending on their political aims and strategies. Similarly, international representatives choose who to meet between the two hierarchies of the Islamic community competing for power in Serbia. More questionable than the change of partners is the fact that among their selected partners, one often comes across the same religious leaders who contributed to the escalation of conflict and violence and who are now, in part due to this international recognition, being promoted into political representatives and potential reconciliators. In the most detailed study on the topic to date, Klaus Buchenau has shown how the leaderships of the two biggest churches, Serbian Orthodox and Roman Catholic, actively participated in delegitimising the Yugoslav state and eventually supported the creation of homogeneous national states in which they would cherish religious dominance. ${ }^{15}$ Both church hierarchies stood by their respective political leadership, even when this was almost certainly leading into war, as is evident in their official declaration in support of independence or separation. ${ }^{16}$ During the wars, together with the Islamic community leadership, they supported the participation of their flock as just and defensive. Finally, as another of Buchenau's investigation of the two churches' rapport with the International Criminal Tribunal for the former Yugoslavia (ICTY) in the Hague shows, after the end of violence, religious leaders actually slowed down the reconciliation process by nourishing a critical stance toward the tribunal. ${ }^{17}$ By condemning the pressure to bring war criminals to justice, these religious leaders have perpetuated the victimhood myth, one of their key discursive tools when addressing the faithful, whereby only churches or religious communities feature as guardians in times of trouble and threat to the nation. To give just one example, Metropolitan Amfilohije of the Serbian Orthodox Church praised Bosnian Serb leader and indicted war criminal 
Radovan Karadžić as the best Serbian son and compared him to Christ on Golgotha prosecuted by the same kind of people as the ones who crucified Christ. ${ }^{18}$

If one is to excuse the Western leaders of ignorance in their practice or selection of religious leaders they meet, that cannot be said of international organisations that are active in the region, such as the interfaith charity Soul of Europe or the German Konrad Adenauer Foundation, which reaffirm the same policy of meeting and promoting religious leaders, rather than projects involving grassroots believers.

\section{Political, legal and financial involvement and policies}

10 Yugoslavia's state-endorsed atheism after 1945 had profound secularising effects, although the early socialist rule also "naturalised" equations of national and confessional categories by their joint supression. From the late 1980s, however, Yugoslavia and its successor states have undergone huge changes in respect to previously discriminated and repressed religious organisations and rights of believers. In addition to changes in laws that boosted the economic and social status of religious organisations, there was a drastic change in the attitude of media, courts and various government agencies in handling matters involving religion and clerics. Religious organisations are relieved from tax obligations, and their representatives have often enjoyed immunity from civil authorities, sometimes even in serious criminal cases, such as numerous cases of paedophilia in both Serbia and Croatia.

11 From the 1990s, the legal framework of religious organisations analysed here was modified along Western models, or more precisely along models of the existing EU members. The close church-state relationship that emerged in most Yugoslav successor states is situated between the state church model found in countries such as Greece and the model of separation and cooperation, as for example in Germany and Austria, where churches are endowed with a variety of social tasks. ${ }^{19}$ In Serbia, a hitherto unknown legal concept of "traditional churches" for seven religious communities was modelled on the Austrian law on religious associations, and was clearly distinct from the previously existing notion of unlimited religious pluralism. ${ }^{20}$ In Croatia, in 1996-97, four government contracts with the Holy See were ratified covering all areas of life, despite serious objections to their constitutionality. ${ }^{21}$ According to their provisions, in addition to the usual legalisation of (Catholic) church wedding and catechism in state schools and nurseries, the Church acquired the status of a legal person, getting the right to open schools, with the state assuming the obligation to support them. Furthermore, the priests of the Catholic Church entered the Croatian army and police, becoming state employees, while the decisions of church courts were forwarded to state courts, which were to implement their civil effects. In the case of a court investigation in which a member of the clergy is involved, prescribed by Criminal Law, the court is obliged to inform the competent Church authorities about it before it takes action. In Bosnia and Herzegovina too, the constitutional provisions of religious freedoms and equality were overridden by bilateralism through which all issues regarding religious denominations have been regulated by later legislations based on agreeements between the state and specific confessions. ${ }^{22}$ While details of new church and state arrangements might differ across former Yugoslavia, a common trait is an arrangement where the dominant (majority ethnic) religious community is privileged by the state, while other religious 
communities are more or less tolerated. Dominant religious communities are further entrusted with organising religious catechism in all levels of state school, with the system criticised as exclusivist, discriminatory and contributing to the polarisation of ethno-confessional differences. ${ }^{23}$

In addition, many political and social requirements concomitant with the accession to the European Union, from restitution of private property to commemoration of the Holocaust or World War II genocide, opened new avenues for social and political engagement of religious organisations dominated by their hierarchies, fortifying their position within nascent democratic states. Most were explained by the need to account for the actions of the Communist authorities, who deprived religious organisations of power and property. "There is no integration in Europe without righting the wrongs from the past", exclaimed Belgrade Catholic Archbishop Hočevar. ${ }^{24}$ Yet sometimes the righting of the wrongs involves new discrimination. The Law on the Restitution of Property adopted by the Serbian Parliament in 2006 foresaw, with regard to the church, the complete restitution of its property, while the return of nationalised property to private individuals is still pending.

Western foundations, such as the Konrad Adenauer Foundation close to the German Christian Democratic party, contributed to the new positioning of religious organisations in Yugoslavia's successor states, and strengtherned their hierarchies and officials through regular contacts, training sessions and seminars, translations of Western publications and transfer of ideas and models. ${ }^{25}$ In Bosnia, World Vision became the most active Christian charity supporting religious organisations in Bosnia, dispensing aid through three major religious organisations, including financing field trips for catechists to foreign countries or events that clearly cement ethnoconfessional identification. ${ }^{26}$ It is this kind of Western support to religious projects and activities that raises eyebrows, given the regular and increasing financial support of religious organisations from respective state budgets after the aforementioned changes, and especially given the widespread dissatisfaction with, and distrust of, the ways religious leaderships use and distribute their resources. Most religious organisations in former Yugoslavia have been directing aid primarily to individuals who are at least nominally members of their denominations. During the siege of Sarajevo, the Adventist Church humanitarian organization ADRA was the only one delivering aid regardless of confessional background or lack thereof. Moreover, there are numerous reports of financial abuse and corruption, for example in the Serbian Church. ${ }^{27}$ Furthermore, as already mentioned religious organisations are exempt from state financial control and taxation, which leads to huge tax evasion and financial manipulations. The most notorious example is that of Medjugorje, the site of alleged Virgin apparitions. The biggest pilgrimage site in former Yugoslavia rose to third most visited Roman Catholic site in the world but remains unofficial and in an economic grey zone. Asja Hadžiefendić-Mešić from Bosnia's Tourism organisation claims that only 18,600 nights were recorded from the estimated 4-5 million nights spent by around 1.5 million pilgrims a year. ${ }^{28}$

14 Vast funds also arrive for religious organisations from the West as donations by the Serbian/Croatian/Bosnyak diaspora. Sandžak Mufti Muamer Zukorlić recently raised many eyebrows stressing that he would only accept donations above $500 €$ during a fund-raising event in Luxembourg for a village cultural centre. ${ }^{29}$ Thereby Zukorlić compared this project with the tallest mosque in the Balkans, which he recently built in 
the remote village of Delimede, home to no more than 300 people but boasting two minarets reaching 80 metres in height. The support from abroad, state aid and privileged legal status have turned religious organisations into powerful institutions. Let us take the example of the Catholic Church in Bosnia and Hercegovina, which serves around 550 thousand Croats ( $80 \%$ of whom declared as believers) and boasts 840 priests and 540 nuns and manages hundreds of educational and other facilities. In terms of media presence, they command four monthly newspapers and a weekly one, 19 radio stations, and three private television stations. ${ }^{30}$ The Serbian Orthodox Church built five hundred churches from 1991 to 2011 and is continuing to build more. ${ }^{31}$ The Islamic Community in Bosnia has also built over five hundred new mosques since the war, in addition to the reconstruction of over a thousand mosques and other religious building. ${ }^{32}$ On the other hand, after more than four decades of restricted activities, religious organisations have been very slow and partial in engaging their clergy or faithful in social and caritative work, especially on a voluntary basis. Some attempts to engage in rehabilitation of drug addicts became notorious for the use of torture and killing in one of them..$^{33}$

15 The above leaves out the most salient example of Western political and financial involvement, namely the reconstruction of places of worship destroyed or damaged during conflicts. This was accorded priority by the Western goverments and aid agencies as an investment in reconciliation led by a common belief that the destruction of cultural heritage should be mitigated by its rebuilding, i.e. creating a common cultural heritage as envisaged in Annex 8 of the Dayton Peace Agreement. In 1996, the European Council adopted a resolution stating that the protection of cultural heritage was of importance for the social and economic development in Bosnia and Herzegovina. European Union agencies, individual European countries and American agencies also footed the bill for the reconstruction of Orthodox churches damaged in Kosovo and led the way in Bosnia, although later on majority Muslim countries and especially Turkey were spearheading the reconstruction and building of Islamic place of worship throughout the region guided by purely religious principles. ${ }^{34}$ The reconstruction of war-damaged, and rebuilding of destroyed, churches and mosques raised many controversies as places of worship were reconstructed or rebuilt even when there were no faithful to use them, with the donors insisting on the argument for their symbolic importance. The symbolism was nevertheless often lost as places of worship were (re)built in different style and scale. Furthermore, no transparent policy existed for prioritisation of places of worship rather than homes or schools or hospitals. Finally, giving priority to the reconstruction of religious buildings appeared to confirm the notion that violence and destruction were committed entirely on religious grounds, so the religious dimension of the war and conflict was elevated and reified as their primary cause. Later on, as described by Višnja Kisić, the EU shelved the troubling questions of guilt, justice and peace, which the reconstruction of religious buildings ought to symbolise, in favour of growth or within the frames of a liberal market economy. ${ }^{35}$ As the symbolism of ethnic cleansing, war, exclusion and destruction could not be replaced by a positive notion of religious buildings as a shared cultural heritage, the interpretative focus changed to heritage reconstruction as job creation and economic development, although the outcome of the latter is similarly difficult to ascertain. 


\section{Fostering interfaith dialogue and reconciliation}

16 While the potential and benefits of interfaith dialogue in former Yugoslavia are frequently lauded, we know much less about its outcome due to a lack of systematic research based on empirical studies and lessons learned..$^{36}$ Before and during the conflict in the 1990s, the most obvious focus in interfaith dialogue was placed on the meetings and negotiations at the highest level. On two occasions the meetings were organised between the Serbian Patriarch Pavle and Croatian Cardinal Kuharić, when the only outcome was two declarations that could hardly testify to their respective churches' attitudes towards the war described above. In addition to the recent conflict, the two Church leaderships contest representations of World War II. ${ }^{37}$ Seventy-five years after its end, and fifty years into their dialogue, the Catholic and Serbian Orthodox Church have not moved the slightest bit in their approach to the events of World War II, which is still the greatest stumbling block in their relations, as lamented by the Apostolic Nuncio in Belgrade..$^{38}$ The number of World War II victims in the interpretation of the two sides differ up to ten-fold, not to mention the image of perpetrators and victims that the two Churches generate. ${ }^{39}$ The Catholic Church in Croatia has for years refused to send official representatives to the commemorations of the victims of the Ustaša terror. When, in 2009, Zagreb Cardinal Božanić finally came to the biggest Ustaša concentration camp of Jasenovac, he stopped short of visiting the actual monument site. Apologising, Božanić instead equated Ustaša and Communist crimes. ${ }^{40}$ In fact, things are getting worse with the process of turning World War II Croatian Cardinal Stepinac into a saint, whereas many in the Serbian Church consider him to be a war criminal. On the other hand, the latter canonised its bishop Nikolaj Velimirović despite his notorious anti-Semitism and links to the Serbian Fascist movement Zbor Leader Ljotić. ${ }^{41}$ Similarly, the representatives of the non-government sector in Croatia in a letter to Pope Francis expressed their concern regarding the opposition of Cardinal Bozanić and Catholic bishops to the use of Cyrillic script as envisaged by law, fearing that it might lead to a deepening of the conflict between Croats and Serbs rather than contribute to reconciliation and the building of lasting peace. ${ }^{42}$ After condemnation by the Serbian bishops, in February 2019, the Croatian Catholic Bishops' Conference published an open letter to the Serbian Patriarch that laid bare all conflicts between the two churches and documented a total lack of communication and common ground that could serve as a basis for future reconciliation efforts. ${ }^{43}$ While the dialogue among Christians died, the one with Muslim leaders never even began in earnest.

Moving away from two church leaderships to bodies and initiatives specifically made with the intent of interfaith dialogue, the most articulated and internationally known is the Interreligious Council of Bosnia and Herzegovina (), created in 1998 upon the initiative of the New York-based World Conference of Religions for Peace, the largest international interfaith enterprise. Still active thanks to political, financial and logistical support by Konrad Adenauer Foundation, Mott Foundation, World Vision, British Council, and the Norwegian and US governments among others, with five fulltime staff, in its agenda it aims to decrease religious prejudice and raise awareness of the importance of inter-religious dialogue and cooperation and promote the improvement of their relationship with the State. American patronage of the Council is often reiterated, and their activities couched in the paradigm of freedom of religion. 
Ambassador Patrick Moon met the leaders of the Council to express his support for their efforts at property restitution and health and pension benefits for clergy. ${ }^{44}$ When opening a three-day meeting of women believers in Trebinje, Bosnia, Steve Gillen, Political Officer of the US Embassy in Sarajevo insisted that, drawing on his own experience as a Roman Catholic, believers contribute to the strengthening of civil society. ${ }^{45}$ In meetings that the Council organises between American diplomats and religious leaders, the latter often express their grievances and lobby for their coreligionists (often against other confessions). ${ }^{46}$

Unfortunately, the representatives of the Council were not available or interested in interviews. Their publications and reports testify about numerous seminars and conferences organised, relying on the work of very few clergymen of each confession and their associates, or often on family members. Council events often bring together religious leaders in Bosnia, but for formal ocasions or common stand against state and other actors, rather than interaction, exchange and eventually mutual rapprochement. Their longest running project is on monitoring and reporting assaults on religious buildings and officials, which falls within American foreign policy on religious freedom. In addition, with the help of the Adenauer Foundation, the Council established the Institute for the Study of Interreligious Dialogue, whose agenda is, however, purely academic, and which has so far organised conferences and produced one anthology of texts from various authors. Its focus again is on religious rights and the protection of religious values. ${ }^{47}$ The organisation of encounters for young theology students is the first move into widening the participation from religious leaders to future religious leaders and pastoral carers. ${ }^{48}$ Yet it remains to be seen how open and exploratory these students can be, knowing the strict hierarchical structure of all three religious organisations they stem from and what the process of becoming a priest/imam entails. Whereas my attempts failed, Fetahagić and Šavija conducted comprehensive research on the activities of the Council as part of their bigger study on interreligous relations in Bosnia and Herzegovina. In conclusion, the rapports between the three dominant religious organisations were characterised as being coloured by a nationalistchauvinist agenda and by maintaining a balance between cooperation and antagonism in order not to affect power relations within religious organisations themselves and one versus the other. The only policy advice for the improvement of interreligious relations could be found in engaging young and grassroots activists away from the existing structures, as established hierarchies would obstruct any questioning of their power. Similarly, the researchers found that the religious leaders at the top of their oganisations and in the Council were increasingly passive, whereas local lower rank clerics were more active in developing and maintaining good relations accross the religious divide. ${ }^{49}$ Unfortunately, foreign and/or Western involvement usually relies on established hierarchies, and often perpetuates and strengthens the power relations within religious organisations.

Another actor in the field is the Faith Foundation set up by Tony Blair, who claimed that the role of religion in conflict had become a diplomatic blind spot compared to the efforts spent to analyse disputes in terms of ideology, economics and ethnic tensions. While this might be a legitimate claim in some contexts, the role of religious belief in the conflict in Kosovo, where his foundation operates, seems grossly exaggerated, if not imposed by Blair and other foreign actors. Charlotte Keenan, the Chief Executive of the Tony Blair Faith Foundation, portrayed the nature of conflict in Kosovo as "a reminder of how old nightmares can rise from the deep freezer of history. Yugoslavia buried the 
idea of national and religious identity, but it sprang back to life with dark and brutal savagery." ${ }^{50}$ Despite the academic concensus against this interpretation of the Kosovo conflict and the reification of religion, with the support of the British Council and the Kosovo Foreign Ministry, the Tony Blair Faith Foundation proceeded to organise conferences with international high-profile participants, while at the same time doing little if anything towards reconciliation on the local level for the benefit of both the faithful and many more of those whose religious affiliation was less or not pronounced at all. ${ }^{11}$ Eventually, in Kosovo, similarly to Bosnia, interconfessional relations barely reach beyond protocol visits and the exchange of greetings on the occasion of major holidays.

20 Contrary to the approach of the Tony Blair Faith Foundation, the Centre for the Study of Religion, Politics, and Society from Novi Sad (many of whose projects were undertaken under the patronage of the (American) National Endowment for Democracy) stated in response to enquiry for this article that they had limited positive experience with faith-based actors, and mainly with the Mennonites and other fringe Protestant groups. According to this Centre, religious hostility came on top of already existing political/economic instability and other causes (mostly nationalist) and religions only provided a set of symbols to deepen the conflict but not to initiate it. As for the dialogue between religious leaders, their position is that religious leaders can only contribute but not head conflict resolution, as they usually have no access to key resources and to the issues which are at the heart of the conflict.

Besides more permanent organisations and initiatives, hundreds of other conferences and gatherings of religious leaders are organised by various other actors. The international meeting "Sarajevo 2012", organised by the Catholic Community of Sant'Egidio, was advertised as the greatest conference of religious and political dialogue since the end of the 1992 war. ${ }^{52}$ Paid for by the Italian Government and European Union, hundreds if not thousands of religious leaders of all faiths, and personalities from the world of culture and politics from more than sixty countries, were flown to Sarajevo to address the most urgent issues of today's society, coexistence and peace, as the organisers announced. Massively and pompously staged, this and similar gatherings raise many questions. First of all, who and on what basis draws up the list of participants, which included bishops never relieved of paedophilia charges, who were eventually forced to resign. ${ }^{53}$ Despite the organisers' efforts, the public reception was muted or manipulated by the media in the region, most of whom report along ethno-confessional lines. Finally, the three days of celebration of bringing leaders of different denominations together were overshadowed by the angry polemic between Serbian Bishop Grigorije of Mostar and Bosnian Reis-ul-ulema Mustafa Cerić. ${ }^{54}$ Similarly, the Ministry of Culture of (Former Yugoslav Republic) North Macedonia with support from UNESCO, the World Islamic League and the World Conference of Religions for Peace also organised several world conferences on interreligious dialogue with hundreds of faith leaders in its Ohrid resort, but besides official conference proceedings volumes it remains difficult to establish any other outcome of these costly gatherings. ${ }^{55}$ Vaguely conceived and without concrete follow-up, these conferences remain fora for encounter and promotion but not for resolving issues that put religious organisations against each other.

Based on the existing research and evidence, the patterns of interfaith relationships that emerge throughout former Yugoslavia are declarative, ceremonial or scholastic. 
Besides big international conferences, religious hierarchs meet only when they invite each other to celebrations. Occasionally, theologians give lectures on each other's theological schools. While some projects, such as student exchange launched by Sarajevo Interreligious Council, are praiseworthy, usually the Council serves as a forum for the three major religious communities to express their views, or more often grievances, and jointly block any attempt to intrude on their positions. Similarly, in other successor states, religious institutions cooperate on common goals such as restitution of property or benefits to their catechists. On a few occasions when religious hierarchies found common language, it served not to promote their mutual dialogue and reconciliation or the proclaimed goal of religious freedom but to address issues beyond their ranks, such as when all major confessions joined the Serbian Church in its rejection of anti-discrimination law in Serbia because it included protection of sexual minorities.

\section{Religious Organisations and Inter-religious Dialogue Three Decades after the Beginning of Armed Conflicts}

Scholarship demonstrated that during the last three decades, religious organisations and leaders in Yugoslavia's successor states have been able to influence political debates and act on a variety of social issues from sexual education to youth camps or theatre plays. ${ }^{56}$ Yet when it comes to their mutual relations, according to Fetahagić and Šavija, they remain at a fragile balance between cooperation and antagonism, necessary for everyday life, while never challenging structural ethno-religious divisions, and thus supressing rathen than resolving any conflicts. ${ }^{57}$ Based on interventions in the spheres of education and politics, as well as public displays, the research by Ljubić and Marko on the leadership of the three main confessional groups in Bosnia saw that among them, dialogue, understanding or consensus is entirely absent. ${ }^{58}$ Bosnia's two biggest churches and the Islamic community have only became more closely intertwined with the respective ethnic and nationalist political parties of Serbs, Croats and Bosnian Muslims (Bosnyaks). In other Yugoslav successor states, there is the same pattern combined with a very high level of declared religiosity. ${ }^{59}$ According to recent research conducted among 4,824 mostly young people from Serbia, Bosnia and Croatia, those who are members of religious communities and hold religious values are less prone to reconciliation, as is evident in the display of distrust, and the refusal to cooperate, forgive and rehumanise former enemies. ${ }^{60}$ The principal investigator Nebojša Petrović explains this "paradox" by the overarching feature of religion as identity marker. Most of those who openly declare religious affiliation are religious not because they accept principles of faith, but in order to stress the only difference between these three peoples or the religion's role as boundary marker.

The greatest responsibility for confessional polarisation remains on the shoulders of higher religious leadership, and Fetahagić and Šavija clearly identify them as acting in concert with exclusivist identity politics, imposing them down the line of command, given the strict hierarchical structures of all major religious organisations. The main narratives of both religious and political actors exhaust themselves in the idea of biological security and survival, never abandoning strict ethno-religious identity politics. Also common to all religious organisations is insistence on confessional religious education in public schools (catechism) as a mainstay of their public presence 
and source of income. However, there is absolutely no evidence that these classes can mitigate youth violence based on ethno-religious hostility. ${ }^{61}$ As the editors of one of the volumes on politicisation of religion in Yugoslavia's successor states point out in their conclusion, the current state of affairs simply leads to the self-reproduction of religious symbols by religious institutions, which operate as their own judge, jury and executioner. ${ }^{62}$ Warmongering by religious leaders might have disappeared, but hate preaching is rampant. Following the public outings of some clerics, one can notice a double talk approach whereby religious leaders refrain from extremist statements and hate speech but do nothing to prevent or disassociate from it when it comes from circles close to them. Thanks to changes in the last three decades, all religious communities now flourish and are active in many spheres of life. There are hundreds of religious charities, youth, women's groups, religious media outlets, publishing houses, cultural and rehabilitation centres and so on, which are all geared to function under the umbrella of their religious community and strictly reflect their structures and views. These religious groups are in turn often closely allied with the nationalist and right-wing groups that breed extremism. When it comes to politics and "national" issues, it is almost by default that the members of these lay or para-religious groups express more extremist positions than the hierarchs, a practice already analysed with the example of the Russian Orthodox Church. ${ }^{63}$ In cases of open hate speech, religious organisations have been also reluctant to punish their representatives and would at best move them to a different role or location. ${ }^{64}$ At the same time, those critical of nationalism in church ranks were removed from positions in teaching and responsibility. ${ }^{65}$

While the role of religion in personal, spiritual and communal welfare is beyond the scope of this article, the Western approaches to religion during and following the armed conflicts in former Yugoslavia with a political agenda, sketched in this paper in its three segments, clearly made little or no impact on the ever-growing ethnoconfessional segmentation in Bosnia and Herzegovina and elsewhere in former Yugoslavia, or on the progress in interreligious dialogue. Instead, by means of "religious" diplomacy, financing religious organisations and vaguely or poorly conceived dialogue and stimulating adherence to rules and practices established in rather different contexts, Western state and non-state actors advertently or inadvertently empower established religious hierarchies and buttress their conservative attitudes, and eventually undermine the assumed goal of reconciliation and peaceful reintegration of the region to Europe and the wider world. Any future engagement needs to come to grips with, rather than ignore, the ever-growing nexus between political and religious elites and organisations, as well as the inner workings of major religious institutions.

\section{NOTES}

1. Among many book-length studies are SELLS Michael, The Bridge Betrayed: Religion and Genocide in Bosnia, Berkeley, University of California Press, 1996; MoJzes Paul (ed.), Religion and the War in 
Bosnia, Atlanta, Ga., Scholars Press, 1998; PERICA Vjekoslav, Balkan Idols, Oxford, Oxford University Press, 2002; DAVIS Scott (ed.), Religion and Justice in the War over Bosnia, New York, Routledge, 1996; VELIKONJA Mitja, Religious Separation and Political Intolerance in Bosnia-Herzegovina, College Station, Texas A\&M University Press, 2003; OGNJENovic Gorana, Jozelic Jasna (eds), Politicization of Religion, the Power of Symbolism: The Case of Former Yugoslavia and its Successor States, New York, Palgrave Macmillan, 2014 and id. (eds), Politicization of Religion, the Power of the State, Nation, and Faith: The Case of Former Yugoslavia and its Successor States, New York, Palgrave Macmillan, 2014. Among scholars there are almost none who argue that there were peace contributions by organised religion in the Yugoslav conflict. The following article recently tried to make this case but its arguments concerning the Medjugorje apparitions were based on very poor empirical grounds. See BARBATO Mariano, DE FRANCO Chiara, LE NORMAND Brigitte, "Is There a Specific Ambivalence of the Sacred? Illustrations from the Apparition of Medjugorje and the Movement of Sant'Egidio", Politics, Religion \& Ideology, vol. 13, $\mathrm{n}^{\circ} 1,2012$, p. 53-73.

2. The religious organisations and hierarchies of the Serbs, Croats and Bosnyaks are the main focus of this article as they were the most involved in recent conflicts and subject of most engagement with Western state and non-state actors. For the symbiosis of confession and ethnicity among the Balkan Orthodox peoples see KITROMILIDES Paschalis in Enlightenment, Nationalism, Orthodoxy: Studies in the Culture and Political Thought of South-Eastern Europe, Aldershot, Variorum, 1994 and my Religious Dissent Between the Modern and the National: Nazarenes in Hungary and Serbia 1850-1914, Wiesbaden, Harrassowitz Verlag, 2006. For South Slav Catholics, see JAKELIC Slavica, Collectivistic Religion: Religion, Choice, and Identity in Late Modernity, Farnham, Ashgate 2010, who introduced a new concept of collectivistic religion for historically embedded religions with the aim of removing their epiphenomenal status with regard to nationalism. For the appearance of ethno-confessional identity of Bosnia and Herzegovina Muslims, see DONIA Robert J., Islam Under the Double Eagle: The Muslims of Bosnia and Hercegovina, 1878-1914, Boulder, Colo., East European Monograph, distributed by Columbia University Press, 1981.

3. My approach here relies on the research framework set by SHAKMAN HURD Elizabeth, Beyond Religious Freedom: The New Global Politics of Religion, Princeton, Princeton University Press, 2015 and BETTIZA Gregorio, Finding Faith in Foreign Policy: Religion and American Diplomacy in a Postsecular World, Oxford, Oxford University Press, 2019.

4. BLumi Isa, "Political Islam Among the Albanians: Are the Taliban coming to the Balkans?" Prishtina, Kosovar Institute for Policy Research and Development, 2005 and "Indoctrinating Albanians: Dynamics of Islamic Aid", ISIM Newsletter 11/02, available at: http://www.isim.nl/files/ newsl 11.pdf; SCHINDLER John R., Unholy Terror: Bosnia, Al-Qa'ida, and the Rise of Global Jihad, St. Paul, MN, Zenith Press, 2007; SHATZMiller Maya (ed.), Islam and Bosnia: Conflict Resolution and Foreign Policy in Multi-Ethnic States, Montréal, McGill-Queen's University Press, 2002; GHODSEE Kristen, "Religious Freedoms versus Gender Equality: Faith-Based Organizations, Muslim Minorities, and Islamic Headscarves in the New Europe", Social Politics, vol. 14, $\mathrm{n}^{\circ} 4,2007$, p. 526-561. Ghodsee raises the issue of the growing number of Muslim states-supported NGOs (in fact, faith-based organisations) advocating for a return to more conservative gender roles in the Balkans. Her concern is that advocating more restricted public roles for women is justified with liberal Western discourse regarding it as "religious freedoms", because women "choose freely" their new roles, or veil.

5. This segment benefited the most from the recent comprehensive survey produced by Sead S. Fetahagić and Nebojša Šavija-Valha for Nansen Dialogue Centre in Sarajevo and financed by the Norwegian Embassy in Bosnia and Herzegovina under the title Between Cooperation and Antagonism. The Dynamics Between Religion and Politics in Sensitive Political Contexts. Case: Bosnia and Herzegovina. 
6. DUFFY TOFT Monica, PHILPOTT Daniel, SHAH Timothy Samuel, God's Century: Resurgent Religion and Global Politics, New York, W.W. Norton \& Co., 2011, clearly connect the modern process of religious resurgence to Israel's victory in the Six-Day War in 1967. Christian CARYL opts for the Soviet invasion of Afganistan and the visit of Pope John Paul II to Poland in his Strange Rebels: 1979 and the Birth of the 21st Century, New York, Basic Books, 2013. What seems universally accepted is that "U.S. foreign policy after the Cold War shows a gradual yet discernible shift in the salience of religion", as Elizabeth PRODROMOU points out in her "U.S. Foreign Policy and Global Religious Pluralism", in Thomas F. Banchoff (ed.), Religious Pluralism, Globalization, and World Politics, Oxford, Oxford University Press, 2008, p. 299. There are no studies about whether there was a similar shift in the policies of West European countries.

7. Among others, BERGER Peter (ed.), The Desecularization of the World: Resurgent Religion and World Politics, Grand Rapids, Michigan, W.B. Eerdmans Publishing, 1999; KEPEL Gilles, The Revenge of God: The Resurgence of Islam, Christianity and Judaism in the Modern World, Cambridge, Polity, 1994; CASAnova Jose, Public Religions in the Modern World, Chicago, University of Chicago Press, 1994; JUERGENSMEYER Mark, The New Cold War: Religious Nationalism Confronts the Secular State, Berkeley, University of California Press, 1993.

8. HAtzopoulos Pavlos, petito Fabio (eds), Religion in International Relations: The Return from Exile, New York; Basingstoke, Palgrave Macmillan, 2003; SNYDER Jack (ed.), Religion and International Relations Theory, New York, NY, Columbia University Press, 2003; THOMAs Scott, The Global Resurgence of Religion and the Transformation of International Relations: The Struggle for the Soul of the Twenty-first Century, New York, Basingstoke, Palgrave Macmillan, 2005.

9. BETTIZA Gregorio, The Global Resurgence of Religion and The Desecularization of American Foreign Policy 1990-2012, a PhD thesis submitted to the London School of Economics and Political Science in 2012, p. 24-25. There is a similar approach in IVANESCU Carolina, "Politicised Religion and the Religionisation of Politics", Culture and Religion, vol. 11, n 4, 2010, p. 309-325. For some early interpretation of the Yugoslav case, see ZRINŠČAK Siniša, "Rôles, attentes et conflits : la religion et les Églises dans les sociétés en transition", Social Compass, vol. 49, n 4, 2002, p. 509-521, and VRCAN Srđan, "The War in Ex-Yugoslavia and Religion”, Social Compass, vol. 41, n 3, 1994, p. 413-422.

10. BUCHENAU Klaus, "Die Rolle der Christen im Balkankonflikt", in Herbert Hoffmann (ed.), Religionsfreiheit gestalten, Trier, 2000, p. 52-86.

11. For analysis of confessional rule during the Ottoman empire, see URSINUS Michael, "Zur Diskussion um „millet“ im Osmanischen Reich”, Südost-Forschungen, vol. 48, 1989, p. 195-207.

12. In 1998, the US Congress passed the International Religious Freedom Act. The Advisory Committee on Religious Freedoms Abroad in the State Department, established in 1996, became in 1999 the Office for International Religious Freedom, with a growing portfolio of grants to promote religious freedom and draft an "Annual International Religious Freedom Report". From 2013, there is also a White House Office of Faith Based and Community Initiatives renamed two years later asinto the Office of Religion and Global Affairs, with the aim to mobilise religious actors and dynamics to advance American interests abroad. Outside of the US government, the United States Institute of Peace began programmes on religion and in identity-based conflicts in the late 1990s. In 1999, The International Center for Religion and Diplomacy was created, followed by The Institute for Global Engagement (2000), The Pew Forum on Religion and Public Life (2001) and other influential thinktanks, academic programmes, etc. For more on human, monetary and time resources within the American government and its local embassies devoted to religious engagement and developing initiatives with an inherently religious agenda, see BETTIZA, The Global Resurgence, op. cit., p. 126-191.

13. BETTIZA, Finding Faith in Foreign Policy, op. cit., p. 89. 
14. SETHURUPAN Nadarajah, "U.S. Wants Roundtables Around Serbia, Bosnia-Herzegovina, Kosovo, Montenegro and Albania”, Norway News, November 20, 2019. http://www.norwaynews.com/u-swants-roundtables-around-serbia-bosnia-herzegovina-kosovo-montenegro-and-albania/

15. BUCHENAU Klaus, Orthodoxie und Katholizismus in Jugoslawien, 1945-1991. Ein serbisch-kroatischer Vergleich. Weisbaden, Harrassowitz, 2004.

16. The Conference of Croatian bishops in their official statement in February 1991 promoted Croatian independence and later actively worked on it using the Catholic Church networks. For their declaration, see "Our Bishops Warn the World", Glas Koncila, 24 March 1991, p. 2. The Holy Synod of the Serbian Orthodox Church sent a letter to the Intenational Peace Conference held in The Hague in November 1991 explicitly stating that "victims of genocide (Serbs) cannot live together with their past and perhaps future executioners (Croats)", thus justifying armed upheaval and violence perpetrated by Serbs in Croatia and supported by the Yugoslav Federal Army. See RADIĆ Radmila, "The Church and the Serbian Question", in The Road to War in Serbia: Trauma and Catharsis, ed. Nebojša Popov, Budapest, Central European University Press, 2000, p. 247-273, here p. 255-262.

17. BUCHENAU Klaus, "Gerechter Krieg. Die Haltung der Serbisch-Orthodoxen Kirche zum Haager Tribunal", Der Überblick 43/1-2, 2007, p. 54-57 and "The Churches and The Hague Tribunal: A Serbian Orthodox and a Croat Catholic Perspective", Forschungsplattform Südosteuropa, available at http://fpsoe.de/.

18. Cfr. "Mitropolit Amfilohije posetio i pričestio R. Karadžića", 26 July 2008, available at http:// www.spc.rs/sr/mitropolit_amfilohije_posetio_i_pricestio_r_karadzica; and "Mitropolit Amfilohije: Najboljim sinovima ovoga naroda sude oni koji su beskrajno gori od njih", 28 July 2008, available at http://www.spc.rs/sr/ mitropolit_amfilohije_najboljim_sinovima_ovoga_naroda_sude_oni_koji_su_beskrajno_gori_od_njih. Metropolitan Amfilohije stressed the same about the late Serbian President Milošević, who was, according to him, put on trial by those who should themselves be tried. See "Srce vuklo u Hag, crkva nije dala" in Politika, 2 February 2013.

19. This refers to a scheme widely acknowledged among sociologists of religion, which groups countries into three models of church-state relations, i.e. one of strict separation (USA, France, some of the successor states to the Soviet Union and others), one of separation and cooperation (Germany, Austria, Italy, Romania and others), and one of a state church (Greece, Malta and others).

20. For a critical examination of Austrian Law in Serbia, see KOHLHOFER Reinhard, "Away with Legal Discrimination - Serbia Shouldn't Follow Austria", Forum 18 News Service, 2 September 2004. 21. ZRINŠČAK Siniša, "Religion and Society in Tension in Croatia: Social and Legal Status of Religious Communities", in J.T. Richardson (ed.), Regulating Religion: Case Studies from Around the Globe, Kluwer Academic/Plenum Publishers, 2004, p. 299-318.

22. ALICINo Francesco, "Religions and Ethno-Religious Differences in Bosnia and Herzegovina: From Laboratories of Hate to Peaceful Reconciliation", in Stato, Chiese e Pluralismo Confessionale, vol. 37, 2016, p. 1-19.

23. See my "Religious Education in Serbia as a Litmus Test for Church-State relations", in Gorana Ognjenovic, Jasna Jozelic (eds), Education in Post-Conflict Transition, New York, Palgrave Macmillan, 2017, p. 211-230; "The Serbian Orthodox Church: Haunting Past and Challenging Future", International Journal for the Study of the Christian Church, vol. 10, n 2, 2010, p. 176-191 and "The New Role for the Church in Serbia", Südosteuropa, vol. 56, n 3, 2008, p. 353-375.

24. In an interview for Dnevnik, 24 December 2012.

25. I.e. the training for journalists of Serbian Orthodox media with speakers from Radio of Bavaria in Munich: http://spc.rs/sr/religija_mediji_radijsko_novinarstvo.

26. One example is the conference of Orthodox Youth entitled "Only Unity Savest the Serbs", as reported on http://spc.rs/sr/samo_sloga_srbina_spasava. 
27. See "Crkvene finansije strogo čuvana tajna", Politika 24 February 2010. The chief accountant of Belgrade metropolitanate stole over one million euros and for years led a dandy lifestyle in impoverished Belgrade: http://www.blic.rs/Vesti/Tema-Dana/366836/Blagajnik-krao-od-SPCpa-letovao-na-Svetom-Stefanu.

28. See "Porezna uprava FBiH zatvorila 14 objekata u Međugorju" in Dnevni avaz, 12 September 2012: $\quad$ http://www.avaz.ba/vijesti/teme/porezna-uprava-fbih-zatvorila-14-objekata-umedjugorju and šABANOVIĆ Faruk, “Međugorje - „crna rupa" turizma u BiH“ available on http:// www.dw.de/me\%C4\%91ugorje-crna-rupa-turizma-u-bih/a-16681094?maca=ser-rssfeed_sve-7443rdf.

29. Video available at https://www.youtube.com/watch?v=bWp72Pg1z5s.

30. ROSSINI Andrea Oskari,"Sarajevo, locus teologicus", available at http:// www.balcanicaucaso.org/eng/Regions-and-countries/Bosnia-Herzegovina/Sarajevo-locusteologicus-161814/\%28from\%29/eng-newsletter.

31. "Molitva među skelama", Večernje novosti 4 November 2011, http://www.novosti.rs/vesti/ naslovna/aktuelno.69.html:352108-Molitva-medju-skelama

32. zoRLAK Kemal, "Dan džamija. Od rata do sada u BiH obnovljeno 1.175 džamija i mesdžida", 7 May 2018, https://www.aa.com.tr/ba/balkan/dan-džamija-od-rata-do-sada-u-bihobnovljeno-1175-džamija-i-mesdžida/1137409.

33. PRICA Dragana, "Peranović osuđen na 20 godina zatvora", Vreme 24 June 2013, http:// www.vreme.com/cms/view.php?id=1122365.

34. The fully transparent report of the European Council's Commission for the reconstruction of the Serbian Orthodox Religious Buildings in Kosovo is available at https://issuu.com/ councilofeurope/docs/ce_ric_serbe_2011_issuu.

35. KISIĆ Višnja, Governing Heritage Dissonance: Promises and Realities of Selected Cultural Policies, European Cultural Foundation, Amsterdam, 2013.

36. BRAJOVIC Zoran, “The Potential of Inter-Religious Dialogue”, in Martina Fischer (ed.), Peacebuilding and Civil Society in Bosnia-Herzegovina: Ten Years after Dayton, Münster, Lit Verlag, 2006, p. 149-179.

37. See BYFORD Jovan, Denial and Repression of Antisemitism: Post-Communist Remembrance of the Serbian Bishop Nikolaj Velimirović, Budapest, Central European University Press, 2008, and for Croatian wartime Cardinal Stepinac, see BRKLJAČIĆ Maja, "Nomen est omen ili Kako je Alojzije Stepinac postao sinonimom za hrvatskog mucenika" and RADIĆ Radmila, "Sporovi i kontroverze srpske/hrvatske istoriografije - Alojzije Stepinac", in Thomas Bremer, Religija, društvo i politika. Kontroverzna tumačenja i približavanja, Bonn, Wissenschaftliche Arbeitsgruppe für weltkirchliche Aufgaben der Deutschen Bischofskonferenz, 2002.

38. See the interview with Archbishop Orlando Antonini, the Vatican's Ambassador to Belgrade in Politika, 3 May 2012: http://www.politika.rs/rubrike/Drustvo/Zalecimo-rane-iz-Drugogsvetskog-rata.sr.html.

39. For an overview of the debates, see SINDBÆK Tea, "World War II Genocides in Yugoslav Historiography", available at http://www.hum.au.dk/forskerskoler/historiephd_old/Tea Sindbaek.pdf

40. коLSтø Pål, "The Croatian Catholic Church and the Long Road to Jasenovac", Nordic Journal of Religion and Society, vol. 24, $\mathrm{n}^{\circ}$ 1, 2011, p. 37-56, here p. 48.

41. BYFORD Jovan, Denial and Repression of Antisemitism: Post-Communist Remembrance of the Serbian Bishop Nikolaj, Velimirovic, Budapest and New York, CEU Press, 2008.

42. http://balkans.aljazeera.net/vijesti/hrvati-pisali-papi-zbog-cirilice The Dean of the Catholic Theological Faculty in Zagreb Tonči Matulić, who deemed that the devil was behind the authors of the letter. See http://globus.jutarnji.hr/hrvatska/koga-slusa-bozanic-. 
43. Pismo biskupa HBK patrijarhu SPC Irineju http://hbk.hr/pismo-biskupa-hbk-patrijarhu-spcirineju/

44. As reported at http://spc.rs/sr/praznici_u_hercegovini

45. As reported at http://spc.rs/sr/konferencija_mrvbih_u_trebinju

46. In “СЛУЖБЕНИК АМЕРИЧКЕ АМБАСАДЕ КОД ЕПИСКОПА АТАНАСИЈА," published on 19 March 2014 at

http://spc.rs/sr/sluzhbenik_americhke_ambasade_kod_episkopa_atanasija. Bihać bishop Atanasije complains about the building of a mosque near the site of a World War II massacre of Serbs and about the generally bad situation for Serbs in territories controlled by Bosnyak Muslims.

47. BRKIĆ Marko-Antonio, Balansiranje između slobode govora i prava na religiju, Sarajevo, Međureligijski Institut, 2012.

48. See MUSLI Emir, "Međureligijski dijalog kao put pomirenja i integracije u BiH", available at http://www.dw.de/međureligijski-dijalog-kao-put-pomirenja-i-integracije-u-bih/a-15610932.

49. Between Cooperation and Antagonism, p. 12-17. Widening the scope of their research by looking at religious education and attitudes towards elections and population censuses, the authors found that higher religious and political structures acted as disturbing agents threatening the maintained delicate balance of local interreligious relations (p. 33).

50. On the Tony Blair Foundation's take on the Kosovo conflict, see "Kosovo Tackles Tough Questions of Religion and Conflict", by Sean Coughlan, 3 July 2013, available at http:// www.bbc.co.uk/news/business-23129474.

51. See the report "Kosovo - Time for Reconciliation", published as part of the project of TransConflict, which is trying to establish relations between Serbian Orthodox monasteries and local Albanian communities, available at http://www.transconflict.com/2012/10/kosovo-timefor-reconciliation-110. The high-profile conferences organised by the Tony Blair Foundation involved the same speakers year after year, with sponsors including the King Abdullah Bin Abdulaziz International Centre for Interreligious and Intercultural Dialogue, Religions for Peace USA, Community of St Egidio and a number of embassies in Pristina. Their activities ceased and, in the meantime, their web site interfaithkosovo is occupied by pornography.

52. http://archive.santegidio.org/pageID/3/langID/en/itemID/4947/The-spirit-of-Assisi-inSarajevo-started-today-Waiting-for-the-September-Meeting-for-Peace.html

53. See TOĖ Rodolfo, "Bosnia: Religion, Nationalism and Pedophilia", http:// www.balcanicaucaso.org/eng/Regions-and-countries/Bosnia-and-Herzegovina/Bosnia-religionnationalism-and-pedophilia-132934/\%28from\%29/eng-newsletter.

54. Reis Cerić insisted that it was clear who needed to beg for pardon and forgiveness after the war in Bosnia. Provoked, Bishop Grigorije replied that he was himself present when Cerić asked for Bosnia to become a Muslim state, just as Jews have their own Jewish state, and that this desire was one of the causes for war. Cerić denied explicitly stating this but insisted he was proud to be a Muslim and that Muslims were a majority in Bosnia, even though some claim they are too numerous and a threat. Cerić stressed there is no Bosnia without Bosnyak Muslims while the others are also welcome. This further angered Bishop Grigorije, who exclaimed that both he and Cardinal Puljić were born in Bosnia, so they need no special welcome. Compiled from Sarajevski “Apel za mir", at http://www.dw.de/dw/article/0,,16233564,00.html?maca=bosTB_bs_oslobodjenje_2-4970-html-cb; http://www.politika.rs/rubrike/region/Dilema-cija-jeBiH.sr.html.

55. KANCESKA-MILEVSKA E. (ed.), Messages d'Ohrid pour la paix et cohabitation: la conférence sur le dialogue interreligieux et inter-civilisationnel, Skopje - Macédoine 26-28 Octobre, 2007, Skopje, Ministère de la Culture de la République de Macédoine, 2008; Id., La religion et la culture - un lien inextricable entre les peuples: deuxième conférence mondiale sur le dialogue inter-religieux et inter-civilisationnel, 
Ohrid, République de Macédoine, 6-8 mai 2010, Skopje, Ministère de la Culture de la République de Macédoine, 2011.

56. See, for example, HEDL Drago, "Sex Education in Croatia. The War Between the Church and Government", available at http://chalkboard.tol.org/sex-education-in-croatia-the-war-betweenthe-church-and-government/.

57. Between Cooperation and Antagonism, p. 9.

58. LJUBić Tatjana, мARко Davor, "Religion, Nation and State: The 'Holy Trinity' of Disunity of Post-Dayton Bosnia and Herzegovina", in Eldar Sarajlić and Davor Marko (eds), State or Nation? The Challenges of Political Transition in Bosnia and Herzegovina. Sarajevo, Center for Interdisciplinary Postgraduate Studies, 2011, p. 151-175, here p. 173.

59. Citizens of the former Yugoslav Republic of Macedonia are the most religious nation in Europe according to the global survey of the Gallup International Religiosity and Atheism Index, which was carried out in November and December 2011 among 52,000 respondents in 57 countries. After nationals of Macedonia, the most religious in Europe are Romanians (89\%), Moldavians (83\%), Poles (81\%), Serbs (77\%). According to Global Religiosity Index, Macedonians are on fourth place. See http://www.wingia.com/web/files/news/14/file/14.pdf.

60. PILIĆ Damir, "Veliko istraživanje o pomirenju Hrvata, Srba i Bošnjaka, Slobodna Dalmacija, 6 October 2012.

61. Between Cooperation and Antagonism, p. 10-11.

62. ogNJENOVIC, JOZELIC (eds), Politicization of Religion, op. cit., p. 211-212.

63. See RICHTERS Katha, The Post-Soviet Russian Orthodox Church, New York, Routledge, 2013, p. 57-74.

64. This was the case of two prominent abbots of Krka Monastery German Bogojević and of Dajbabe Monastery Nikodim Bogosavljević.

65. This was the case of Franciscan Drago Bojić, director of interfaith and intercultural centre "Zajedno" [Together] and the most vocal critic of nationalism in church ranks, who was removed from editing Franciscan monthly Svjetlo riječi and banned from teaching at the Franciscan Theology Faculty in Sarajevo.

\section{ABSTRACTS}

The paper examines to what extent the policies of the United States and West European countries and international organisations affect ethno-confessional segmentation, political attitudes of religious leaders and institutions and contribute to the goal of stabilisation and peaceful reintegration of the successor states of former Yugoslavia to Europe and the wider world, which most of them purport to achieve. It does so by three-tier level analysis into: 1) Symbolic promotion of religious leadership; 2) Political, legal and financial involvement and policies; 3) Fostering interfaith dialogue and reconciliation.

Cet article pose la question de la façon dont les politiques des États-Unis, des pays d'Europe occidentale et des organisations internationales affectent la segmentation ethno-confessionnelle, les attitudes politiques des dirigeants et des institutions religieuses et contribuent à l'objectif de stabilisation et de réintégration pacifique des États successeurs de l'ex-Yougoslavie dans l'Europe et dans le monde, objectif que la plupart d'entre eux entendent atteindre. L'analyse se développe à trois niveaux: 1) celui de la promotion symbolique des dirigeants religieux;2) celui des 
politiques et de l'implication politique, juridique et financière ; 3) celui de l'encouragement du dialogue et de la réconciliation interconfessionnels.

\section{INDEX}

Geographical index: Yougoslavie

Mots-clés: ex-Yougoslavie, dialogue interconfessionnel, politicisation de la religion, organisations religieuses

Keywords: former Yugoslavia, interfaith dialogue, politicization of religion, religious organisations

\section{AUTHOR}

BOJAN ALEKSOV

University College London, School of Slavonic and East European Studies b.aleksov[at]ucl.ac.uk 